\title{
Brexit: the links between domestic and foreign policy
}

\section{Introduction}

The issues and factors that have influenced Britain's impending departure from the EU have been much debated since the landmark referendum vote of $23^{\text {rd }}$ June 2016 . Yet it is the longer-term interaction between domestic politics and foreign policy-making can arguably be seen to be of major significance in shaping this development. To what specific degree domestic politics have shaped the path to Brexit is therefore is therefore worth analysing across a significant historical timescale, namely to assess how a cataclysmic foreign policy development has arisen from within the machinations of internal British politics and made such an impact on the international political environment.

\section{International relations beyond the Cold War}

The 'realist' theory of international relations is sceptical of the significance of domestic internal politics on a state's conduct within foreign affairs. This perspective argues that the internal/domestic dynamics of a regime are not relevant in determining its actions within the international arena. Instead, most realists argue that a state's foreign policy is primarily shaped by either 'Hobbesian' national self-interest, or instead in the neo-realist tradition by the international structure and its contemporary 'balance of power'. However, 'liberal' IR theorists alternatively emphasise the significance of internal political factors and structures in shaping a state's behaviour in foreign policy matters. They argue that liberal-democratic states with regular internal election cycles and public accountability operate with enhanced 
mutual co-operation in foreign affairs. This is often in response to the public mood at domestic level, and therefore generates a different type of behavioural 'predictability' among states than the realist perspective. This liberal viewpoint therefore advocates that states will co-operate to establish international 'norms' and procedures for wider collective benefit, and according to this outlook, institutions such as the United Nations and European Union symbolise such liberal values and principles in practical action.

Within this context, since the end of the Cold War between the USA and Soviet Union (circa 1990-91) in particular, there have been significant shifts in the dynamics involved in the relationship between domestic and foreign affairs. From a specifically British context, its own foreign policy direction has reacted to various global events, namely the vacuum created by the Soviet Union's sudden demise, the ascent of American unipolarity, and the rise of other notable powers such as the EU and China. However, of equal importance have been various internalized factors linked to UK domestic politics, notably relating to tensions arising from EU integration and associated policies impacting on British society, and in turn the public reaction which has fuelled a steady growth of Euroscepticism.

\section{John Major's administration}

As the UK's first post-Cold War British Prime Minister, John Major faced various complex foreign policy issues between 1990-97, notably ongoing EU integration, the first Gulf War following the 1990 Iraqi invasion of Kuwait, the Yugoslav civil war (1992-95), and often testing relations with the world's single superpower, the USA. Major also instigated the early stages of the Northern Irish peace process, which had significant foreign policy implications with 
both the Americans and the Republic of Ireland in particular. However, in domestic terms, Major was weakened by inheriting office from another leader in the middle of a parliamentary cycle, and even after winning power in his own right was restricted by a small parliamentary majority. This vulnerable domestic position was certainly a significant variable that impacted on his capacity for effective international diplomacy while he was in office.

The issue of European relations was arguably the dominant one of the Major premiership, and some have described it as a 'fault-line' that pervaded and destabilised it. In many ways therefore, the troubled European policy developments symbolised the clear connection between this administration's particular domestic circumstances and its subsequent foreign policy, and the first steps to Brexit can be traced back to this period in particular. The Maastricht Treaty, signed in early 1992, saw the EEC formally officially become $\mathrm{EU}$, and its more federalist and integrationist image from this date heightened existing concerns among Eurosceptics on the Conservative backbenches. When Major was re-elected in April 1992, his new administration governed with a reduced parliamentary majority of just 21, which weakened his status both at home and within the international community and created problems in formally implementing the Maastricht Treaty into law. A bigger majority would certainly have strengthened his capacity for stronger leadership on European policy matters, and after the UK's shambolic exit from the Exchange Rate Mechanism (ERM) in September 1992, the mood towards Europe among some Conservative MPs hardened further. A series of prolonged parliamentary debates on the Maastricht bill followed throughout 1993-94, and further damage to Major's authority was caused by various rebellions by his own MPs on this issue. In late 1994 he withdrew the 'whip' from eight Conservative rebel MPs due to their continued opposition to EU policy, and such events 
adversely affected his domestic political credibility alongside his ability to negotiate and manage relations with the European Union.

These ongoing Europe-related difficulties exacerbated pre-existing Conservative internal political divisions and were highlighted as one of the most significant factors in the party's catastrophic 1997 general election performance, which produced its lowest number of MPs since 1906. This scenario would therefore strongly suggest that domestic political factors, arising from Major's weak status in Parliament, were a pivotal reason for his European policy struggles, and which consequently further undermined his position among increasingly restless MPs, the British public, and the wider international community. This scenario created the ideal conditions for burgeoning British Euroscepticism, with UKIP forming in 1993. A Prime Minister with a stronger parliamentary majority could have been bolder in foreign affairs, not just EU matters, as evident in Tony Blair's greater ambition after 1997. In short, a weak domestic position adversely affected Major's ability to conduct effective foreign policy that could successfully maximise the country's interests. This created tensions (both internal and external) which would have significant implications for Britain's role within the international community and its future membership of the European Union in particular.

\section{The New Labour era}

Major's beleaguered government, crippled by EU policy matters, was crushed by Tony Blair's Labour landslide of 1997. This development significantly changed the UK's political landscape, with the Blair administration explicitly pledging domestic 'modernisation', improved relations with Europe, while also promoting an 'ethical foreign policy'. The unprecedented 
parliamentary of majority of 179 provided Blair with a position of political strength that could deliver efficient and competent statecraft like few governments before or since. This could potentially be utilised in both domestic and foreign policy terms, with Blair keen to prove that his administration would be more effective than Labour governments of the past, as well as transcend perceived weaknesses in various policy areas under the Conservatives between 1990-97.

Fuelled by his huge majority, Blair operated with greater authority in both domestic and foreign policy spheres, and in the foreign domain this was particularly evident in areas where Major had struggled to make significant political progress- most notably regarding a peaceful settlement within Northern Ireland and in cultivating more constructive relations with both the EU and the USA. Regarding the delicate issue of European matters, Blair embraced a more positive approach and signed key treaties at Amsterdam in 1997 and Nice in 2000, which reflected a relatively constructive phase of UK-EU relations; with Blair's improved focus aligned to his stronger domestic position and Europhile perspective. However, initial proposals to join the European single currency (Euro) and then an EU Constitution were abandoned due to negative public opinion. Blair consolidated Major's initial diplomacy in relation to Northern Ireland, and improved relations with the EU assisted this particular policy area, as European financial and diplomatic support boosted Northern Irish stability. This sense of enhanced political direction and authority had greater impact on the province, as evident in the landmark 1998 Good Friday Agreement.

Unlike Major, Blair's stronger domestic position shaped more consistently positive relations with US President Bill Clinton, and this was also influenced by their 'modernising' 
tendencies, with both seeking to abandon 'leftist' ideology and embrace the 'radical centre'. Until Clinton's departure from the presidency in early 2001, the first four years of Blair's administration witnessed flourishing post-war Anglo-American relations, although there were some tensions over the Balkans region, with Blair more enthusiastic for military intervention in the late 1990s to stabilise the aftermath of the Yugoslav civil war. Blair expressly desired to maintain Britain's historic 'special relationship' with the American superpower, and he also maintained a close proximity to the foreign policy agenda of President George W. Bush (from early 2001). This was despite Bush's different political values (compared to both Blair and Clinton), with his conservative Republican affiliation and a 'neo-conservative' view of foreign affairs. Nevertheless, Blair consistently supported the post-9/11 'war on terror' narrative and specifically the military endeavour in Iraq, arguing that his closeness to Bush could influence American foreign policy-making. Consequently, even with a divided public opinion and discontent among his own MPs, Blair won the approval of Parliament for use of British military force in Iraq in early 2003. This was despite a rebellion of 139 Labour MPs and the resignation of senior ministers, yet his dominant domestic parliamentary position saw him prevail. This episode further illustrated that a Prime Minister's specific domestic circumstances can determine their pursuit of a specific and often controversial course of foreign policy.

Yet the failure to find Iraqi 'weapons of mass destruction' (WMDs) and the chaotic post-war aftermath signalled the start of a significant breakdown of trust between the British government and the wider public, with public opinion subsequently reflecting a sense of unease about the justification for war, and this distrustful mood towards the governing 'elite' would persist until the EU referendum in 2016. Blair's 'liberal interventionist' support for the Iraq War ultimately saw him prioritise the transatlantic alliance with the USA over Europe, 
and this consequently further fractured relations between Britain and most of the EU, as most of the EU led by the prominent Franco-German axis were opposed to the conflict. Such dynamics further impacted on broader British public opinion and its increasingly challenging attitude regarding relations towards the EU on a range of policy issues. Iraq eroded Blair's reputation to such an extent that it hastened his departure from office in summer 2007, with his successor Gordon Brown's major foreign policy priority being to minimise the Iraq conflict's damaging legacy and to constructively manage relations with the ever-challenging European Union; an issue which was increasingly antagonising UK public opinion and facilitating the rise of parties such as UKIP. EU-related policy controversy again surfaced with the Lisbon Treaty of 2007, which Brown was willing to cautiously support, although by this stage he was operating with a relatively small parliamentary majority and reduced authority having not been elected Prime Minister in his own right, while facing a revitalised opposition led by David Cameron which was demanding a referendum on the Lisbon issue. While Brown was credited for the 'statesmanlike' way he dealt with the globalised economic crisis of 2008-

9, he was domestically weak and deteriorating economic conditions were certainly a factor in his electoral defeat in 2010, when Labour's vote share was its lowest since 1983. Brown and Labour may well have lost power anyway after thirteen years in office, but the scale of defeat was sharpened by externalised pressures and a growing public mood of distrust, and the longer-term connections to the eventual Brexit vote were clearly now set in motion.

\section{Conservatives and Brexit}

David Cameron headed the first Conservative administration for thirteen years, yet was restricted in his political power as he headed a coalition government that was reliant on 
formal support from the minority partners, the Liberal Democrats. With the divisive issue of Europe having an increasingly high-profile influence on British politics, Cameron led an increasingly Eurosceptic party that due to specific electoral circumstances was forced to work in political partnership with enthusiastic Europhiles. This was a recipe for political instability, and would perhaps explain his early decision to abandon the previous high-profile pledge to hold a referendum on the Lisbon Treaty, causing much anger both within his own party and elements of public opinion, and further facilitating the steady growth of UKIP and broader public Euroscepticism. While this could be viewed as a pragmatic reaction to managing proEuropean Liberal Democrats within his Cabinet, an internalized party backlash appeared in late 2011, when 81 Conservative MPs voted to hold a referendum on EU membership, although an actual national public vote was highly unlikely, largely due to the government's coalition status. This instigated the beginning of a 'slow-burning' fuse, whereby an issue with major implications for both domestic and foreign policy would progressively undermine Cameron's leadership.

UKIP's anti-EU agenda generated sufficient public appeal to finish $2^{\text {nd }}$ in the 2009 European Elections and by 2014 it topped this national poll, an unprecedented achievement for such a recently established party. The party's increasing popularity and capacity to erode Conservative support remained a significant and recurring domestic problem for Cameron's leadership between 2010-15, and its growth formed a key part of his broader electoral strategy. By the time of the 2015 general election, opinion polls indicated that UKIP was a potent electoral threat to many Conservative MPs, with fears that it could either take Conservative seats directly, or more likely, attract enough traditional Conservative voters to boost Labour in marginal constituencies. On this premise, Cameron pledged to hold a 
referendum on EU membership if he was re-elected in May 2015, and in making this manifesto commitment (while Labour did not), he boosted Conservative prospects amidst a close-fought election campaign. Cameron consequently achieved a narrow parliamentary majority of 12 , securing the first Conservative parliamentary majority in 23 years despite the UKIP vote reaching $12.6 \%$. Yet he was now committed to holding a referendum on Britain's continued EU membership, a foreign policy issue with potentially huge domestic repercussions. Although in a slightly stronger position than 2010, in domestic terms Cameron was still relatively weak after 2015 , with a small parliamentary majority and increasingly vulnerable to his own Eurosceptic MPs who viewed the EU with escalating hostility.

Theresa May's emergence as UK Prime Minister in July 2016 was a further reflection of these explicit links between foreign and domestic politics, as David Cameron's political demise was explicitly caused by the EU referendum result of $23^{\text {rd }}$ June 2016 . The narrow 'leave' verdict was largely not anticipated by most of the political and media classes, and it sealed Cameron's political fate. Subsequently, this volatile foreign policy issue, which had impacted on British politics for a generation, now appeared to have a decisive outcome, and Cameron resigned with his reputation irrevocably damaged. Similar to Blair and Iraq, Cameron's initial modernising image had become distorted by external 'foreign' pressures, although in his case emanating from Europe; an ironic development given that it was a policy area he'd once claimed was a divisive waste of the party's time. Within these dramatic circumstances, Theresa May's priority was to implement the policy of Britain leaving the European Union, (known as "Brexit"), and which has escalated into an overwhelming political priority that has eclipsed all other policy matters in its wake. 
Consequently, May's premiership has found this dominant 'Brexit' policy narrative an extremely difficult one to deal with. She has subsequently faced significant challenges in formulating and devising Britain's future global role with a range of international bodies and institutions, while the counterbalance of the Anglo-American relationship has been instilled with unexpected friction due to the unpredictable actions of President Trump. As an unelected Prime Minister, May desired to strengthen her position regarding such critical foreign policy areas, (specifically relating to Brexit negotiations), and this led her pursuing what proved to be a catastrophic domestic gamble. In calling an early and unnecessary general election for 8th June 2017, May unexpectedly lost her parliamentary majority. This domestic catalyst emanated from a volatile and unpredictable public mood and a party split by Brexit. This consequently weakened her position as perceived by British public opinion, while also undermining both her authority over her Cabinet and her image in the wider international community. These negative side-effects were the polar opposites of what she hoped to achieve in calling the election. Her administration is subsequently in a far less secure or stable position towards ongoing EU diplomatic negotiations, and this has generated a vague and unpredictable vision of Brexit as the departure date of March 2019 looms closer on the horizon. These recent and dramatic political events are further testimony to the fact that the connections between domestic and foreign politics have been clearly evident throughout this prolonged process of European integration over many years dating from the end of the Cold War, and such dynamic interactions between these different spheres of political statecraft has undoubtedly driven matters towards the inexorable endgame of the UK's departure from the European Union.

\section{Dr. Ben Williams, University of Salford}

